\title{
Introduction: the changing context of comparative social policy
}

\section{Patricia Kennett}

The field of comparative social enquiry has grown dramatically since the 1960 s, in terms of the amount of studies being undertaken, the range of approaches used and the countries analysed. The analytical emphasis on the notions of modernization and convergence, and social expenditure as a proportion of GNP as the measure of welfare effort, whilst still evident in contemporary cross-national research, ceased to dominate the comparative landscape during the 1980s. There is now much more interest in recognizing and explaining qualitative as well as quantitative differences in types of welfare systems, an acknowledgement that formal social policies are only one element in the arrangement of welfare and that social policy is not just about ameliorating the impact of social inequality or altruism but itself contributes to social divisions in society. There has been a greater recognition of diversity and the importance of analysing context, processes and the outcomes of social policies in different countries and their impact on different groups.

The changing discourse around social policy and the welfare state can also be associated with the economic and political conditions of the 1980s, which were in marked contrast to what had gone before. In many OECD countries post-1945 was an era in which the notion of Keynesian welfare capitalism, in its various institutional forms, incorporated a commitment to extended social citizenship and a certain minimum standard of life and security as a matter of right. National welfare regimes helped to underpin a global system of interacting national economies characterized by mass production and mass consumption. This model of institutionalized, bureaucratic provision and social rights was perceived as the inevitable outcome of a 'modern' or developed society. By the 1980 s it was the political rhetoric of deregulation, privatization, the efficiency of the 'free market' and rolling back the frontiers of the state that had become the global economic discourse influencing both national and international policies. According to Taylor-Gooby (2001) in a European context '... Keynesianism (the view that state intervention is the best way to promote growth and employment) is quite simply dead, a result of the general acceptance that governmental capacity to manage investment within its borders is limited' (p. 19). At the same time many of the fundamen- 


\section{A handbook of comparative social policy}

tal assumptions associated with the national welfare state and the social rights of citizenship have been discredited and renegotiated, and the discourse about the role of the state in welfare has moved in a new direction (Taylor-Gooby, 2001; Kennett, 2001). Harris (2002) contrasts the 'new' welfare of the last two decades which centres on personal and community relationships (Etzioni, 1995, 1997; Driver and Martell, 1997), community governance and the notion of active membership, with the 'old' welfare of the post-war period with emphasized society, universal citizenship rights and statutory state provision (King and Wickham Jones, 1999; Rose, 1999). Fundamental to the 'new' welfare is a re-balancing of the social contract between the state and the individual, between rights and responsibility and between different spatial scales.

The current context then is one in which many of the old certainties of the past have been eroded, and the predominantly inward-looking, domestic preoccupation of social policy has made way for a more integrated, international and outward approach to analysis. Central to this endeavour is a reassessment of the place of the state in contemporary social policy analysis. The preeminence of the national scale, the national state and the national citizen has been weakened by internationalization, the growth of multi-tiered networks and partnerships, and the re-emergence of the regional and the local within national states. There has been a proliferation of scales, channels, projects and social networks through which social interaction and active participation can be pursued. Thus, within the modern world system the notion of unfettered state sovereignty has become problematic and contradictory (Clapham, 2002; Weiss, 2003) and has presented new challenges for comparative analysis in the social sciences.

These challenges have been captured in recent academic debates relating to processes of globalization which have contributed to a de-centring of the state in social policy analysis. The burgeoning literature reflects the multifaceted nature of global processes, and indeed the vagueness and inconsistencies in the use of the concept (Geshiere and Meyer, 1998). General debates have been concerned with the economic, cultural, technological, social and political dimensions of the phenomenon. More recently, the relationship between globalization, social policy and the welfare state has generated interest amongst commentators (for example Deacon et al., 1997; Midgley, 1997; Mishra, 1999; Yeates, 2000; Scharf, 2000; Swank, 2002). This interest has emerged in the context of the retrenchment and reorientation of welfare mentioned earlier and the changing role of the state as its dominant position has increasingly been challenged by transnational institutions and the assertiveness of subnational governments. Global processes are said by some to have contributed to the erosion of the functions of nation-states and deprived national governments of their ability to establish and maintain an autono- 
mous welfare model. Clearly there are differing opinions on the nature, extent and impact of global processes on social policy and welfare systems. What is more certain is that the current context of social policy is one which looks beyond the boundaries of the state in terms of incorporating transnational and subnational activities, and which is sensitive to the nature of the mixed economy of welfare and the range of conduits through which policies are made and delivered. For Gershiere and Meyer the concept of globalization is inspiring precisely because it requires social scientists to reconsider and reflect upon their objects of study as well as 'seek for more appropriate fields of investigation which take account of peoples actual entanglement in wider processes' (Geshiere and Meyer, 1998: 603).

So in de-centring the state the researcher is encouraged to reconsider established structures of 'boundedness' and to seek out alternative orientation points and identify reconstructed boundaries as individuals, communities and societies seek to make sense of a changing world.

It is in this context then that this handbook brings together the work of key commentators in the field of comparative analysis in order to provide comprehensive, but by no means exhaustive, coverage of contemporary debates and issues in cross-national research. Organized around five themes, the collection explores the contextual, conceptual, analytical and processual aspects of undertaking comparative social research. The first part - 'The state and social policy in a globalizing world' - is concerned with extending the epistemological framework through which cross-national analysis is explored. The four contributors to this part draw on the theme of globalization to explore the future of the nation-state and the nature of governance, and the implications for human security and social protection in different societies and for different groups of people.

Bob Jessop (Chapter 1) identifies the transfer of powers previously located at the national level to a more diverse, multi-level and multi-sector range of actors and institutions. In addition, he stresses the increasing importance of looking 'beyond the state' in order to understand the future of national and/or nation-states and recognize that it is 'embedded in a wider political system, other institutional orders, and the lifeworld' (p. 12 this volume). Whilst pointing out that the boundaries and institutional structures of states are socially constructed and vary over time and across space, Jessop identifies the demise of the Keynesian welfare national state and its replacement by a Schumpeterian workfare post-national regime. Within this regime the emphasis is on innovation, flexibility and open economies, the erosion of the social wage and a subordination of social policy to the needs of a flexible labour market and an economy able to compete in the global market place.

The implications of this and other aspects of recent structural change on women are the concern of Jill Steans (Chapter 2). Her emphasis is on the 


\section{A handbook of comparative social policy}

gendered nature of globalization and world order and the significance of the public and private realms in reshaping identities and roles in both developed and developing countries. The differential impact of globalization on the states and societies of the North and the South is also a concern of Andrés Pérez-Baltodano in Chapter 3. He investigates the range of social policy responses to the crisis of security created by processes of globalization. He outlines the formation and development of the democratic western European state and, drawing upon this 'universalist' model, considers the different levels of 'stateness' achieved by countries in the North and the South. He argues that an understanding of the varying capacities of states to respond to global pressures is vital in order to fully comprehend the varying conditions of human security across societies. To this end, his focus on the North and South provides a useful comparison in that they 'represent categories for differentiating levels of institutional and regulatory capacity to create conditions of order and security at the national level' (p. 57 this volume).

In the final chapter of Part I (Chapter 4), Ramesh Mishra focuses on Australia, Japan and the post-socialist countries of Eastern Europe and the former USSR as representative of societies with institutional patterns defined as 'social protection by other means'. He argues that these were developed during an era of relatively closed and insulated national economies and considers the extent to which they have been undermined by the opening up of national markets to international competition.

The reassessment of the role of the state in social policy analysis forms part of a fundamental reappraisal of the assumptions embedded in social science research which has been under way since the 1980s. The rationality, essentialism and universalism of policy discourse and practices through which the welfare state was established have been called into question. The emphasis on diversity, difference and contingency and the notion of spatial and temporal variation challenged many of the assumptions on which the theoretical and epistemological traditions of social policy have been built. With this in mind Parts II and III of this volume focus on the conceptual and theoretical frameworks for analysing social policy cross-nationally.

In Chapter 5 Jochen Clasen begins by exploring the distinctive features of and the meanings applied to comparative social policy over recent years. For comparativists the unit of analysis has traditionally been different national contexts. However, as the boundaries of state and society are becoming increasingly blurred the concerns for Graham Crow in Chapter 6 are 'What do social scientists compare? Are the concepts of state and society still relevant in cross-national analysis?'.

Chapters 7 and 8 question the dominance of the Western social research paradigm in comparative analysis. Alan Walker and Chack-kie Wong critically assess the way in which the concept of the 'welfare state' has been 
utilized in cross-national analysis. They conclude that the Western ethnocentric construction of the concept has resulted in the exclusion of large sections of the globe from comparative research. Julia Tao reconceptualizes the nature of human need and social obligation from the Chinese Confucian moral tradition.

Attempts to categorize and typologize different aspects of welfare systems across countries have been an extremely popular feature of comparative social research. This approach is exemplified in the work of Gøsta EspingAndersen (1990) which represents a major contribution to the field of cross-national analysis. His identification of the 'Three Worlds of Welfare Capitalism' is referred to in many of the chapters in this collection. The five chapters in Part III are concerned with extending and broadening the analytical, conceptual and substantive aspects of categorizing and typologizing welfare states. Walter Korpi and Joakim Palme begin by building a typology of welfare states based on their institutional characteristics and the consequences for inequality and poverty of different types of welfare system (Chapter 9). In Chapter 10 Julia O'Connor links the contested concepts of gender, citizenship and welfare regimes to explain the variations in the range and quality of social rights. She urges that 'gender, race and class and their interaction must be integral parts of comparative analysis' (p. 197 this volume). This is echoed by Norman Ginsburg in Chapter 11 who adopts a 'critical structured diversity' approach to explore cross-national developments in social policy. For Ginsburg this approach enables the researcher to retain the specificity of each national context, whilst also incorporating elements 'beyond the state' within the analysis. It also incorporates consideration of the relationship between the welfare state and the social divisions of race, class and gender.

The final two chapters in this section are concerned with the relevance of classificatory and explanatory models for analysing social welfare in the countries of the South. In Chapter 12 James Midgley points to the need for 'appropriate, normative frameworks that can address the persistence of global poverty, mass deprivation, oppression and other pressing problems' (p. 218 this volume) both in the North and in the South. He outlines the social development perspective and argues that this approach can make a major contribution to this effort. In contrast, Ian Gough's response (in Chapter 13) has been to 'radically recast' the welfare regime paradigm. He provides a variegated, middle-range model that can facilitate fruitful and integrated analysis across the North and South of the globe.

In Part IV - The Research Process - the focus, as the title suggests, is the day-to-day reality of preparing for and carrying out cross-national social policy analysis. It is concerned with recognizing and exploring the issues that emerge when researching in more than one country. In Chapter 14 Linda Hantrais discusses the relevance and implications of recognizing and under- 


\section{A handbook of comparative social policy}

standing different research cultures and disciplinary traditions. In the following chapter (Chapter 15) Else Øyen uses research on poverty to highlight the difficulties and advantages of adopting a comparative focus. Chapter 16 (Patricia Kennett) emphasizes and demonstrates the need to develop appropriate and robust concepts and an understanding of the ways in which social problems are constructed in order to effectively analyse issues in different national contexts. Homelessness is used as a concrete example to highlight the 'elasticity' of definitions not only within national contexts but also internationally, and the implications of this for data collection. Chapters 17 and 18 respectively (Steen Mangen and Mattei Dogan) are concerned with qualitative and quantitative approaches in cross-national analysis.

The final part of this collection is intended to highlight continuing and emerging themes and issues which could prove of particular relevance to understanding the contemporary social world. There is evidence of increasing inequality and polarization in the distribution of wealth as the opportunities of globalization are unevenly distributed between nations and people. Graham Room (Chapter 19) considers the various ways in which social exclusion has been analysed in the European Union during the last 30 years and considers the possibilities for future research, whilst Ray Forrest (Chapter 20) explores the nature of the housing question for the 21st Century. For David Nelken (Chapter 21) it is not just the emergence of new types of crime such as transnational organized crime or sexual tourism that can be associated with globalization. Global processes have also exacerbated differences between countries, regions, cities and even parts of cities which, according to Nelken, has provided 'both the conditions and alibi for much crime' (p. 377 this volume). In the final chapter in this volume Ian Holliday (Chapter 22) discusses the rapid developments in information technology and e-government and considers the ways in which the policy process and social policy are being re-shaped. He points to the strengthening of global networks, the potential for new forms of political participation, policy making and social policy, as well as the deepening of inequalities and the international digital divide. These are aspects of The Informational Age that should and could be integrated into and better understood through comparative policy analysis.

\section{References}

Clapham, Christopher (2002), 'The challenge to the state in a globalized world', Development and Change, 33 (5), 775-95.

Deacon, Bob, with Michelle Hulse and Paul Stubbs (1997), Global Social Policy. International Organizations and the Future of Welfare, London: Sage Publications.

Driver, Stephen and Luke Martell (1997), 'New Labour's communitarianisms', Critical Social Policy, 17 (3), 27-44.

Esping-Andersen, Gøsta (1990), The Three Worlds of Welfare Capitalism, Cambridge: Polity Press.

Etzioni, Amitai (1995), The Spirit of Community, London: Fontana. 
Etzioni, Amitai (1997), The New Golden Rule, Community and Morality in a Democratic Society, New York: Basic Books.

Geshiere, Peter and Birgit Meyer (1998), 'Globalization and identity: dialectics of flow and closure. Introduction', Development and Change, 29, 601-15.

Harris, Patricia (2002), 'Welfare rewritten: change and interlay in social and economic accounts', Journal of Social Policy, 31 (3), 377-98.

Kennett, Patricia (2001), Comparative Social Policy: Theory and Research, Buckingham: Open University Press.

King, Desmond and Mark Wickham-Jones (1999), 'Bridging the Atlantic: the Democratic (Party) origins of welfare to work', in M. Powell (ed.) New Labour, New Welfare State? The Third Way in British Social Policy, Bristol: The Policy Press.

Midgley, James (1997), Social Welfare in Global Context, Thousand Oaks, CA and London: Sage Publications.

Mishra, Ramesh (1999), Globalization and the Welfare State, Cheltenham, UK and Northampton, MA, USA: Edward Elgar.

Rose, Nicolas (1999), Powers of Freedom: Reframing Political Thought, Cambridge: Cambridge University Press.

Scharf, Fritz W. (2000), 'The viability of advanced welfare states in the international economy, vulnerabilities and options', Journal of European Public Policy, vol. 7, pp. 190-228.

Swank, Duane (2002), Global Capital, Political Institutions and Policy Change in Developed Welfare States, Cambridge: Cambridge University Press.

Taylor-Gooby, Peter (ed.) (2001), Welfare States under Pressure, London: Sage Publications.

Weiss, Linda (ed.) (2003), States in the Global Economy. Bringing domestic institutions back in, Cambridge: Cambridge University Press.

Yeates, Nicola (2000), Globalisation and Social Policy, London: Sage Publications. 
Patricia Kennett - 9781845421588 Downloaded from PubFactory at 04/26/2023 12:03:27PM via free access 